\title{
Kritične tačke unapređenja izbornog sistema Bosne i Hercegovine - rubikon demokratizacije ${ }^{1}$
}

\author{
Adis Arapović \\ Docent Fakulteta za upravu Univerziteta u Sarajevu, \\ adis.arapovic@fu.unsa.ba
}

\begin{abstract}
Rezime: Usporena ili blokirana implementacija izbornih rezultata nakon Općih izbora 2018. produbila je ukupnu političku krizu u $\mathrm{BiH}$, pa ni 20 mjeseci nakon izbora nisu u potpunosti provedeni izborni rezultati. Izborni sistem BiH tako postaje trajni katalizator političkih blokada, te kao takav usporava ili blokira proces konsolidacije parlamentarne demokratije. Posljednja tri izborna ciklusa nedvojbeno su potvrdila paradoks izbornog sistema pa i Izbornog zakona BiH. Naime, svi relevatni akteri, od izborne administracije, preko domaćih i međunarodnih nezavisnih izbornih posmatrača, do samih političkih subjekata, iako s nizom utemljenih primjedbi i dokumentiranih anomalija u izbornom procesu, u principu priznaju izborne rezultate $\mathrm{i}$ istovremeno jednoglasno zagovaraju temeljito unapređenje izbornog sistema. Ova studija daje teorijski i empirijski uvid u ključne odredbe izbornog zakonodavstva ili kritične tačke izbornog sistema koje se nužno moraju inovirati, redefinirati i modernizirati kako bi konsolodacija parlamentarne demokratije, efikasan politički sistem, odgovorna izvršna i zakonodavna vlast, te povjerenje građana i izborni sistem postali aksiomi društveno-političkih reformi u procesu eurounijskih i unutrašnjih integracija.
\end{abstract}

Ključne riječi: izborni sistem Bosne i Hercegovine, Izborni zakon, izborno pravo, izborni principi, političke stranke, Bosna i Hercegovina

\section{Osnove izbornog sistema $\mathrm{BiH}$}

Iako u protekle dvije decenije jeste dao određeni doprinos uspostavljanju vladavine zakona u političkoj areni, demokratizaciji i legitimnom političkom pluralizmu, izborni sistem Bosne i Hercegovine još uvijek nije u potpunosti baziran na univerzalnim aksiomima općeg, jednakog i tajnog prava glasa, te slobodnim i neposrednim izborima za sve državljane BiH s biračkim pravom. Izborni sistem $\mathrm{BiH}$ nije dostigao savremene demokratske standarde koji podrazumijevaju pet izbornih principa:

\footnotetext{
${ }^{1}$ Ovaj rad predstavlja nastavak istraživanja izbornog sistema u Bosni I Hercegovini, te je uz značajne korekcije, dopune i stilska unapređenja ovdje prezentiran kao ekstenzija ranije objavljenog rada u formi Policy Briefa, izdavača Škole za političke studije Vijeća Evrope u Bosni i Hercegovini.
} 
- tajnost glasanja,

- slobodne izbore,

- neposredne izbore,

- jednako biračko pravo i

- opće biračko pravo.

Izborni sistem Bosne i Hercegovine definiran je pojedinim odredbama Ustava Bosne i Hercegovine, te nižih nivoa vlasti, kao i paketom izbornog zakonodavstva u šta ulazi Izborni zakon $\mathrm{BiH}$, te još 13 zakona državnog ili nižeg nivoa, kako slijedi:

1. Zakon o sukobu interesa u institucijama vlasti u $\mathrm{BiH}$;

2. Zakon o finansiranju političkih stranaka u $\mathrm{BiH}$;

3. Zakon o popunjavanju upražnjenog mjesta člana Predsjedništva $\mathrm{BiH} u$ toku trajanja mandata;

4. Izborni zakon Republike Srpske;

5. Izborni zakon Brčko distrikta;

6. Zakon o izboru, prestanku mandata, opozivu i zamjeni načelnika općina u Federaciji BiH.

7. Zakon o sukobu interesa u institucijama vlasti u Federaciji BiH;

8. Zakon o sprečavanju sukoba interesa u institucijama vlasti u Republici Srpskoj;

9. Zakon o sukobu interesa u institucijama Brčko distrikta;

10. Zakon o finansiranju političkih stranaka iz budžeta Brčko distrikta;

11. Zakon o političkim organizacijama SR Bosne i Hercegovine;

12. Zakon o političkim organizacijama Republike Srpske;

13. Zakon o političkim organizacijama Brčko distrikta

Također, ustave entiteta, kantona, statute gradova, općina/opština možemo smatrati dijelom izbornog sistema Bosne i Hercegovine. Izborni sistem $\mathrm{BiH}$ jeste kombinacija gotovo svih poznatih izbornih principa: većinski princip i jednočlane izborne jedinice npr. za izbor sastava Predsjedništva $\mathrm{BiH}$, zatim proporcionalni princip višečlane izborne jedinice za izbor sastava parlamenata, prag od 3\% za redovne mandate putem poluzatvorenih preferencijalnih listi, preferencijalno glasanje (liste otvorene biračima), te prag od $5 \%$ za kompenzacione mandate, zatim različiti preferencijalni pragovi unutar liste od 10\% i 20\%, itd., zbog čega izborni sistem Bosne i Hercegovine možemo smatrati kombiniranim ili hibridnim sui generis izbornim sistemom, jedinstvenim na svijetu.

Ovako heterogen i nedovršen izborni sistem nerijetko omogućava kršenje ustavnih principa i međunarodnih konvencija o ljudskim pravima, te $u$ 
kombinaciji sa nepotpunim provođenjem zakona, omogućenim izbornim zloupotrebama, neadekvatnom reakcijom tužilaštava i sudova, često generira političke krize i nestabilne parlamentarne većine, jer su malverzacije i zloupotrebe u izbornom procesu postale pravilo, a ne izuzetak.

Usporena ili blokirana implementacija izbornih rezultata nakon Općih izbora 2018. produbila je ukupnu političku krizu u BiH, pa ni dvije godine nakon izbora nisu u potpunosti provedeni izborni rezultati (npr. nije formirana nova izvršna vlast u Federaciji: predsjednik, potpredsjednici, Federalna vlada, kao ni Vlada HNK). Izborni sistem BiH tako postaje katalizator političkih blokada, te kao takav usporava ili blokira proces konsolidacije parlamentarne demokratije. Posljednja tri izborna ciklusa nedvojbeno su potvrdila paradoks izbornog sistema pa i Izbornog zakona BiH. Naime, svi relevantni akteri, od izborne administracije, preko domaćih i međunarodnih nezavisnih izbornih posmatrača, do samih političkih subjekata, iako s nizom utemeljenih primjedbi i dokumentiranih anomalija u izbornom procesu, u principu priznaju izborne rezultate $\mathrm{i}$ istovremeno jednoglasno zagovaraju temeljito unapređenje izbornog sistema.

Također, svi pobrojani akteri, te stručna javnost posebno, jedinstveno zastupaju stavove da je aktuelni Izborni zakon, kao i sistem u cjelini, zastario, neadekvatan, nedovršen, kontradiktoran, te kao takav nužno generira političke tenzije i problematizira legalitet i legitimitet političke vlasti, pa se sve češće zagovara njegova temeljita reforma. Nezaobilaznim se zato čini pitanje da li je Izborni zakon uopšte moguće još uvijek restaurirati, dopunjavati, popravljati, prilagođavati presudama sudova, realitetima koje politički život proizvodi? Ili je integralna rekonstrukcija izbornog sistema, što uključuje novi Izborni zakon, ali i nekoliko drugih zakona, nezaobilazna reforma i naredna faza demokratizacije i unutrašnje konsolidacije Bosne i Hercegovine? Jednako važno, kako postići politički konsenzus, na kojim načelima i prioritetima pri reformi izbornog sistema, ukoliko znamo da se političke reforme u $\mathrm{BiH}$ u proteklih 10 godina provode vrlo ograničeno, nesistematski i sporo?

\section{Izborni sistem Bosne i Hercegovine kao agens diskriminacije}

Izborni sistem može se definirati na dva načina, tj. u užem i širem smislu. „U širem smislu, pod ovim pojmom podrazumijeva se skup svih mjera i radnji koje su regulirane pravnim propisima jedne zemlje, a odnose se na izbore $\mathrm{i}$ izborno pravo. U užem smislu, pod pojmom izbornog sistema, podrazumijeva se jedan njegov element, a to je izborna formula, odnosno način raspodjele 
mandata“" ${ }^{\text {‘ }}$ Temeljna uloga izbornog sistema u demokratski organiziranoj drŽavi je kreiranje institucionalnog okvira unutar kojeg će se poboljšati i osnažiti demokratski poredak, transparentnost izbornog procesa i održavanje slobodnih i poštenih izbora, gdje građani imaju povjerenje u sistem transpozicije njihove političke volje činom glasanja za svoje predstavnike u vlasti. Neki od vodećih autoriteta savremene politologije poput Arend Lijpharta i Giovanni Sartoria ističu da je izborni sistem veoma bitan segment političkog sistema od čijeg oblikovanja suštinski zavisi i njegovo funkcioniranje. Lijphart izborni sistem opisuje kao najvažniji element predstavničke demokratije, dok Sartori smatra da je izborni sistem najbitniji dio djelovanja političkog sistema. Izborni sistem nije tek puki okvir i ne treba zanemariti njegov značaj za same rezultate izbora, što je na primjeru Bosne i Hercegovine posebno indikativno. Zbog toga je bitno podsjetiti da, kada se jednom utvrdi, izborni sistem počinje generirati veoma značajne i dugotrajne posljedice. Izborni sistem je izuzetno bitan za stabilnost društva, ili drugačije rečeno, nedovršen ili anomaličan izborni sistem može biti agens društvene nestabilnosti.

U Bosni i Hercegovini uspostavljen je proporcionalni izborni sistem sa većim brojem višemandatnih jedinica, što je ponajviše uslovljeno složenim političkim sistemom tj. ustavnom arhitekturom Bosne i Hercegovine. Naime, „,najviše zbog dvoentitetskog modela, kojeg prate višečlane izborne jedinice, bilo je neophodno utvrđivanje istovremenog postojanja proporcionalnog i kompenzacionog izbornog sistema ${ }^{36}$. „Zahvaljujući kompenzacionom izbornom sistemu došlo je praktički do, što nije uobičajena izborna praksa, miješanja dva nivoa izbornih cenzusa (od 3-5\%), (...). “4

Vidljivo je da je u sistemu raspodjele nekih mandata, naglašena namjera zaštite teritorijalnih i/ili etničkih kolektivnih interesa, nasuprot građanskom suverenitetu i zaštiti individualnih prava i interesa, uključujući jednako aktivno i pasivno biračko pravo. Naprimjer, način izbora članova Predsjedništva Bosne i Hercegovine, izbor Predsjednika/potpredsjednikâ Republike Srpske kao i izbor delegata u Dom naroda Bosne i Hercegovine onemogućuje pripadnicima „nekonstitutivnih“ naroda, nacionalnih manjina i neopredijeljenih isticanje kandidature ili izbor u ove organe, što je presudom Evropskog suda za ljudska prava (ECHR) u predmetu Sejdić\&Finci označeno suprotnim Evropskoj konvenciji za zaštitu ljudskih prava i fundamentalnih sloboda, te

\footnotetext{
${ }^{2}$ Pravni leksikon, (Beograd, 1970), 378-379.

${ }^{3}$ Mirjana Kasapović, Izborni leksikon (Zagreb, 2003), 198.

${ }^{4}$ Florian Bieber, „Institucionaliziranje etničnosti: postignuća i neuspjesi nakon ratova u Bosni i Hercegovini, na Kosovu i u Makedoniji”, 25, Forum Bosnae (2004), 31-47, at 36.
} 
kao takvo mora biti promijenjeno i usklađeno sa ovom Konvencijom, odnosno onemogućiti daljnje postojanje ove vrste diskriminacije.

Iako je funkcija izbora da, između ostalog, „obezbijede predstavljanje i uspostave legitimitet“, kako bi se „vladi proslijedili zahtjevi naroda“, jer, čak i ,autoritarni režimi održavaju izbore i onda kada oni nisu takmičarski“"5, izborni sistem Bosne i Hercegovine, osim što nominalno sadrži neke elemente liberalno-demokratske tradicije pluralizma, jednako sadrži i određene recidive totalitarizma, te političke, etničke, teritorijalne i rodne diskriminacije.

Posljednji opći, predsjednički i parlamentarni, izbori u Bosni Hercegovini održani u oktobru 2018. godine, prema stajalištima međunarodnih institucija, održani su u vrlo kompliciranom izbornom sistemu. Prema izvještaju OSCE-ove posmatračke misije (ODHIR), ,pravni okvir je detaljan i uglavnom pogodan za demokratske izbore. Međutim, i dalje ostaju značajni dugotrajni nedostaci kao što su ograničenja na pravo kandidovanja, što osporava principe univerzalnog i jednakog prava glasa i zabrane diskriminacije koji su predviđeni obavezama i opredjeljenjima OSCE-a, Evropskom konvencijom o ljudskim pravima (ECHR) i drugim međunarodnim standardima. Jednako pravo glasa je dodatno osporeno neredovnim revidiranjem granica izbornih jedinica što je u suprotnosti od onoga kako zakon nalaže. Većina prethodnih ODIHR-ovih preporuka nisu uzete u obzir što uključuje i uvođenje djelotvornih odredbi o sprječavanju zloupotrebe državnih sredstava, finansiranju kampanja i nadziranju finansiranja kampanja i rješavanju izbornih sporova. Izražena je ozbiljna zabrinutost zbog manjka političke volje da se pristupi ustavnim i izbornim reformama. (...) Nakon dana izbora, brojni kandidati su opisali izborni proces kao pun prevara i javno su doveli u pitanje validnost rezultata. Politički subjekti su govorili o navodnim izbornim malverzacijama na dan izbora, uključujući "krađu” glasova tokom brojanja, kupovinu glasova, namjerno poništavanje važećih glasačkih listića i pristrasno učešće Općinskih izbornih komisija (OIK) u procesu.(...) ${ }^{\text {‘6 }}$

Nakon izbora 2018. ponavlja se situacija iz 2011. godine kada je za formiranje Vlade Federacije BiH trebalo 6, a za formiranje Vijeća ministara 15 mjeseci političkih pregovora. U trenutku kreiranja ovog teksta, u septembru 2020. godine, dakle tačno dvije godine nakon održanih izbora, još uvijek nisu formirane vlade $\mathrm{u}$ jednom kantonu i na nivou Federacije $\mathrm{BiH}$, što znači da izborni proces i provedba izbornih rezultata nisu okončani u skladu

\footnotetext{
${ }^{5}$ Andrew Heywood, Politics (New York, 2002), 435-436.

${ }^{6}$ Bosnia and Herzegovina General Election 2018, Final Report of Election Observing Mission OSCE/ ODIHR, 2018, 1-2.
} 
sa propisanim rokovima, čime su grubo prekršene odredbe izbornog zakonodavstva i dodatno pogoršana politička klima. Posljedica navedenog jeste produbljivanje nepovjerenja građana u pravni poredak i demokratski proces generalno.

\section{Reforma izbornog zakonodavstva - minimum konsenzusa za političku stabilizaciju}

„Rijetki su primjeri konstituiranja izbornih sistema za koje se može tvrditi da su rezultat pažljivog uređivanja na osnovu historijskih, etničkih, političkih, kulturoloških, tehničkih i drugih kriterija ${ }^{7 “}$. Češći su primjeri da se izborni sistem kreira iz dva osnovna razloga: ,zato što politički akteri nemaju dovoljno informacija i znanja o konsekvencama pojedinih tipova izbornih sistema, pa posežu za ,političkom transplantacijom“ nekog izbornog modela koji se koristi kao uzor, a drugi razlog je što izborni akteri svoja znanja koriste za promociju onog izbornog sistema koji uvećava njihove šanse u izbornoj utakmici“"8.

Iako je do sada izvršen veliki broj izmjena u izbornom sistemu, posebno u Izbornom zakonu Bosne i Hercegovine, još uvijek postoje ozbiljne prepreke koje usporavaju konsolidaciju parlamentarne demokratije i funkcioniranje izbornog sistema na osnovnim principima slobodnih izbora: tajnosti i slobode glasanja, neposrednih i posrednih izbora, te jednakog biračkog prava i općeg biračkog prava. Naime, u samom Izbornom zakonu BiH postoji veliki broj značajnih nedostataka, nedorečenosti, kontradiktornosti i anomalija koje kumulativno ugrožavaju održavanje transparentnih, demokratskih, fer i poštenih izbora. Izborni sistem Bosne i Hercegovine još uvijek u velikoj mjeri odražava dominaciju ili supremaciju etničkih kolektiviteta u odnosu na pojedinca ili građanina, u smislu kako se njegovo značenje i uloga shvataju u evropskim društvima parlamentarne demokratije.

Naravno, izborni sistem je determiniran odredbama i principima na kojima počiva ustavno uređenje Bosne i Hercegovine, pa svaka kritika izbornog sistema, u stvari počinje kritikom hibridnog ustavnog poretka. Međutim, analizirajući aktuelni izborni sistem $\mathrm{BiH}$, može se zaključiti da postoji niz nedostataka koje primarno osporavaju aktivno i pasivno biračko pravo, te podstiču nejednakost i diskriminaciju. Može se zaključiti da se izborni sistem, tačnije biračko pravo oslanja na etničku i teritorijalnu pripadnost, što je suprotno Ustavu Bosne i Hercegovine, gdje se insistira na promociji individualnih

\footnotetext{
${ }^{7}$ Vladimir Goati, et.al., Preporuke za izmenu izbornog zakonodavstva u Srbiji, (Beograd, 2008), 44; ${ }^{8}$ Ibid.
} 
ljudskih i političkih prava. Ipak, kao krajnji rezultat, politička prava u BiH ne predstavljaju individualna prava svakog građanina ili pojedinca nego su više prava kolektiviteta, dok su dodatno u slučaju $\mathrm{BiH}$, kolektivna prava zagarantirana samo pripadnicima triju najvećih nacionalnih grupa u zemlji, odnosno trima konstitutivnim narodima. U stvari, demokratski princip jednakog biračkog prava u $\mathrm{BiH}$ nije postignut, jer se višestruko krši pasivno biračko pravo (ograničavanjem prava kandidiranja na određenu teritoriju i na pripadnost određenom narodu), te aktivno biračko pravo (ograničavanjem izbora kandidata samo određenog naroda i s određene teritorije).

Dokazujemo time, između ostalog, da su ljudska i politička prava reducirana na etnička prava. Prema važećim rješenjima, na izborima ne biraju građani, već narodi, a oni koji se biraju, nisu građani već pripadnici naroda ili predstavnici teritorije, često etnički predisponirane. Ovakva koncepcijska matrica, konzervira stanje etničke podijeljenosti, konstituira geografsko-etničke paradigme, stimulira aparthejd i regresira demokratsku konsolidaciju države i društva. Prema međunarodnim standardima o ljudskim pravima, svaki pojedinac ima pravo na aktivno i pasivno biračko pravo na cijeloj teritoriji države u kojoj živi, a ne samo jedno od tih prava na nekom njenom dijelu, a na drugom ne. Rješenjima u normativnom dijelu Ustava $\mathrm{BiH}$ poništen je politički građanin u korist etničkog političkog predstavljanja, jer je zapostavljanje činjenica iz preambule Ustava koja identificira i ,građane“ kao konstitutivne subjekte koji su utvrdili Ustav $\mathrm{BiH}$, pa normativne odredbe Ustava BiH prepoznaju samo Bošnjake, Srbe i Hrvate, njihova kolektivna prava i kolektivne identitete u ostvarivanju ustavnih prava na političko predstavljanje. Prema tome, „osnova političke reprezentacije nije građanin, već nacija i nacionalni identitet. Umjesto promocije individulanih interesa i prava građana, politički interesi se oblikuju na nacionalnoj osnovi, a to znači na kolektivitetu“" .

Sumarno posmatrano, osamnaest godina od donošenja Izbornog zakona, te preko dvadeset izmjena i dopuna koje su uslijedile između 2002. i 2019. godine, s velikom sigurnošću možemo ustvrditi da ovakav izborni sistem, nužno treba reformirati, uskladiti s presudama međunarodnih i domaćih sudova, te na najmanju moguću mjeru svesti brojne anomalije, koje mogu značiti korekcije onih dijelova izbornog zakona koje se tiču metodologije i tehnologije provedbe izbora, a manje ustavnih i političkih odredbi koje traže široki politički konsenzus.

\footnotetext{
${ }^{9}$ Mirko Pejanović, Politički razvitak Bosne i Hercegovine u postdejtonskom periodu, (TKD Šahinpašić,
} 2005), 54. 
Izborni reinženjering, promjene ili reforme u izbornom sistemu neke zemlje, razumijevaju se kao jedan normalan, pa čak i dobrodošao potez ako donosi optimizaciju, pozitivnu političku dijalektiku i normativni iskorak. Kako navodi Sartori, dosadašnja praksa pokazuje da je reinženjering i odabir izbornog sistema bio posebno fundamentalan i značajan za (re)konstituiranje demokratije u postsocijalističkim društvima. Izborni sistem nije neutralan regulativni mehanizam, već jedan od ključnih faktora za formiranje političke scene u zemlji, koji zahtijeva periodično preispitivanje.

\section{KRITIČNE TAČKE REFORME IZBORNOG ZAKONA}

Iz prethodno opisanih razloga, dok se ne dese konstitucionalne reforme na nivou ustava države i entiteta, te komplementarno tome - suštinske promjene u izbornom sistemu, od presudne je važnosti osigurati manje složene, ali jednako važne tehničke korekcije Izbornog zakona koje će osigurati zadovoljavanje principa za održavanje fer, transparentnih i poštenih izbora. Demokratski ambijent za slobodne i fer izbore, moguće je kreirati uz prethodno zadovoljavanje sljedećih preduslova, odnosno intervencija u izbornom zakonodavstvu:

\section{Legitimitet predstavljanja kolektiviteta}

Izražen problem izbornog sistema jeste legitimitet predstavljanja kolektiviteta, odnosno različito tumačenje legitimiteta, zavisno da li se mandat razumijeva kao mandat povjeren predstavniku ili pripadniku konstitutivnog naroda. Ovaj problem eskalirao je na izborima 2010, a ponovio se 2018. godine, kada je izbor hrvatskog člana Predsjedništva, od strane vodećih stranaka s hrvatskim predznakom ili hrvatskih nacionalnih stranaka, proglašavan nelegitimnim uz primjedbu da je izabrani član Predsjedništva iz reda hrvatskog naroda izabran većinom ne-hrvatskih glasova. S druge strane, ustavne i zakonske odredbe definiraju da se u Predsjedništvo BiH iz Federacije biraju „po jedan član iz reda“ bošnjačkog i hrvatskog naroda, što implicira da je taj član eksplicitno „pripadnik“, a eventualno ,implicitno“ predstavnik tog naroda u Predsjedništvu BiH. Slična anomalija dešava se i na parlamentarnim izborima već nekoliko ciklusa unazad, kada su pojedini kandidati, radi veće vjerovatnoće neposrednog ili posrednog izbora u jedan od parlamentarnih domova, mijenjali vlastitu etničku pripadnost. Pitanje izbora člana Predsjedništva bih iz reda hrvatskog naroda, predstavlja bitnu prekretnicu u reformi izbornog sistema, te poligon za konsenzus između individualističkog (građanskog) i 
kolektivističkog (etničkog) principa, a mogućnosti instrumentalizacije etničke pripadnosti moraju biti minimizirane.

\section{Provodivost cjelokupnog izbornog ciklusa i vanredni izbori}

Uspostavljanje funkcionalnih mehanizama koji će osigurati provodivost izbornih rezultata bez mogućnosti da bilo koji subjekt ili razlog blokira konstituiranje parlamenata i izbor izvršne vlasti, makar posljednja opcija bila i prijevremeni, odnosno ponovljeni izbori za nivo vlasti gdje izborni ciklus nije doveden do kraja. Ovo podrazumijeva manje korekcije izbornog zakona u dijelovima koji opisuju konstituiranje parlamenata na svim nivoima, posredno konstituiranje domova naroda, te naravno izvršne vlasti, izborom predsjednika entiteta, te vlada na svim nivoima. Primjera radi, u ovom trenutku 24 mjeseca nakon Općih izbora 2018. Federacija BiH nema ni kandidata za Predsjednika i potpredsjednike $\mathrm{FBiH}$, čime ni prvi preduslov za izbor i imenovanje nove Vlade nije ispunjen, a odgovornost se ne može jednostavno adresirati, niti ima načina da se proces okonča pravnim lijekovima.

Također, vanredni ili prijevremeni izbori, shodno evropskoj izbornoj praksi, trebali bi se propisati i za neke druge kritične slučajeve, npr. neusvajanja budžeta do kraja trećeg mjeseca za tekuću godinu, neodržavanje ili nesazivanje sjednica vlada i parlamenata duže od 100 dana, itd.

Jednako važno, održavanje i Općih i Lokalnih izbora tokom jedne kalendarske godine, s minimalnim razmakom od šest mjeseci, svake četiri godine, značajno bi umanjilo političke tenzije koje se u dvogodišnjim ciklusima ili čak kontinuirano dešavaju jer se zemlja svake druge godine nalazi u tzv. izbornim godinama.

\section{Jednaka vrijednost glasa}

Vrijednost glasa nije ni približno ista u svim izbornim jedinicama, posebno u Federaciji BiH, pa je za parlamentarni mandat u jednoj dovoljno nekoliko stotina glasova, a u drugoj nije dovoljno ni nekoliko hiljada glasova. Izostanak prava dijela birača iz Brčko distrikta da biraju svoje predstavnike u kantonalne skupštine, a time posredno i domove naroda viših nivoa, narušeno je jednako biračko i opće pravo na predstavništvo. Korekcija granica izbornih jedinica u Federaciji BiH, shodno novijim statističkim podacima zakonska je obaveza i imperativ za zaštitu principa jednake vrijednosti glasa. 


\section{Integritet izbornog procesa}

Osim drugih sistemskih elemenata zaštite integriteta izbornog procesa, pitanja izbornih malverzacija koje ne spadaju u sistemske anomalije, već više $\mathrm{u}$ incidentne obrasce moguće je bez velikih otpora tretirati kroz novi paket reformi.

Pročišćavanje biračkih spiskova i interoperbilnost podataka između matičnih ureda i općinskih izbornih komisija po pitanju korekcije biračkih spiskova u realnom vremenu (uz moguće odstupanje od 24 sata u sticanju i gubitku biračkog prava), ne traži nikakvu osim tehničku/profesionalnu odgovornost.

Glasanje putem pošte mora biti podložno višem nivou kontrole, pri čemu se slanje glasačkih lsitića poštom pokazalo kao jedan od uzroka i načina korumpiranja izbornog procesa,a rješenje leži u dokazu o prebivalištu glasača u odsustvu.

Sprječavanje manipulacije sastavima biračkih odbora, neposredno pred izborni dan, kao što je to bila masovna pojava na Općim izborima 2018, otkloniti presudnu ulogu biračkih odbora u legalnom provođenju izbornog procesa, odnosno regularnosti glasanja i brojanja glasova.

Bolja zaštita prava i uloge stranačkih i nestranačkih posmatrača dobrim dijelom može osigurati regularnost i transparentnost izbornog procesa, posebno na sam izborni dan, što do sada nije bio slučaj, zbog čestih opstrukcija rada $\mathrm{i}$ osnovanih prigovora posmatrača.

Zabrana korištenja javnih resursa za nosioce javnih funkcija koji su ujedno i kandidati na izborima može se urediti izbornim, ali i krivičnim zakonodavstvom, uz vremenski ograničeno djelovanje normi na period trajanja izborne kampanje (30 dana).

Sprječavanje tzv. „lažnih kandidatura“ u situacijama kada nosioci političkih funkcija, primarno (grado)načelnici bivaju nosioci listi na Općim izborima, ali obrnuto, kada nosioci izvršnih funkcija ili parlamentarnih mandata učestvuju u kandidaturama na lokalnim izborima, da bi nakon što privuku potrebni broj glasova za osvajanje jednog ili više mandata vlastitom listom, odustali od mandata i prepustili ga sljedećem kandidatu koji može imati drastično lošiji rezultat. Potrebno je preispitati ovu praksu, kao i praksu neograničenog broja mandata načelnika, jer su to rijetke političke funkcije s neposrednim izborom u izvršnoj vlasti na kojima nema ograničenja broja uzastopnih mandata, za razliku od npr. članova Predsjedništva $\mathrm{BiH}$ ili bilo koje druge rukovodeće funkcije u javnom sektoru. 


\section{Depolitizacija stalne izborne administracije}

Brojni su argumenti, koje malo koja relevantna adresa osporava, da je od velike važnosti depolitizirati, odnosno na minimum svesti utjecaj političkih stranaka ili pojedinaca na rad stalne izborne administracije: Centralne izborne komisije (CIK) i općinskih izbornih komisija (OIK). S tim u vezi, od velike je važnosti minimizirati partiokratski pritisak, te preko temeljnih organa izbornog sistema osigurati zaštitu integriteta i povjerenja u izborni proces nepristrasnom, profesionalnom i efikasnom izbornom administracijom. Primjera radi, izbor novih članova CIK-a tokom 2020. godine označen je kao krajnje kontroverzan s obzirom na odsustvo transparanetne i kompetitivne procedure predlaganja i izbora kandidata, te izostanak provjere njihove stranačke neovisnosti.

\section{Usitnjenost stranačke ponude i izborni pragovi}

Jedan od očiglednih problema u provedbi izbornih rezultata i formiranju izvršne vlasti jeste i usitnjen stranački sastav parlamenata, gdje i najveći stranački klubovi nemaju više od 30\% mjesta, pa je za formiranje stabilnih parlamentarnih većina sve češće potrebna široka koalicija od tri i više partnera. To nužno donosi dugotrajan pregovarački proces oko formiranja koalicija, brojne tačke razilaženja partnera, mnogo uslovljavanja, te na koncu matematičke većine bez čvrstog koalicijskog ugovora, jasnog programa djelovanja i međusobnog povjerenja. Takva platforma djelovanja u pravilu umanjuje efikasnost vlada, generira političke tenzije i otvara prostor za prebjege, odnosno prelazak pojedinaca iz jednog u drugi stranački klub, čime se remete ili čak potpuno mijenjaju parlamentarne većine.

Individualno vlasništvo nad mandatom u kombinaciji s niskim izbornim pragom od 3\% pokazuje se kao destabilizirajući izborni mehanizam, a politička korupcija prilikom „kupovina“ ili „ucjena“ nosilaca mandata presudno određuje oblik parlamentarne većine, te time i koncentracije moći u zakonodavnoj i izvršnoj vlasti. Stoga je vrlo bitno preispitati mehanizme zaštite kredibiliteta parlamenata i izabranih predstavnika građana, a ukoliko to znači podizanje izbornih pragova na 4 ili 5 posto, ili pak razmatranje vlasništva nad mandatom, posebno kompenzacionim, izborni i stranački sistem mogao bi biti usavršen.

Broj političkih stranaka u $\mathrm{BiH}$ po glavi stanovnika trenutno je najviši u Evropi, a razloge za to ne treba tražiti u visokoj političkoj kulturi, već u divergiranom stranačkom sistemu koji podstiče političku korupciju, gdje se većina 
političkih subjekata registrira radi trgovine utjecajem i korumpiranja izbornog procesa, a ne radi takmičenja za glasove birača. Trgovina mjestima u biračkim odborima od strane marginalnih političkih stranaka, konfuzija koja se u političkoj utakmici kreira i fiktivna ponuda na glasačkim listićima, razlozi zbog kojih treba preispitati pooštravanje kriterija za formiranje, djelovanje, a posebno za učešće na izborima svim političkim subjektima.

\section{Unutarstranački izborni prag}

Posljednjim izmjenama i dopunama Izbornog zakona, tzv. unutarstranački preferencijalni prag podignut je s $5 \%$ na $10 \%$ za Lokalne, te $20 \%$ za Opće izbore. Ova korekcija išla je u prilog zaštiti pozicije žena na listama, i vrlo vjerovatno je osigurala viši nivo učešća neposredno izabranih žena u zakonodavnim organima. Istovremeno, podizanje praga svelo je na minimum vjerovatnoću da preferecijalni glasovi promijene redoslijed kandidata na listi, odnosno da veći broj glasova nekih kandidata njima omoguće osvajanje mandata. Iako se nekoliko takvih slučajeva izdvaja, model poluotvorenih listi s preferencijalnim glasanjem, uz unutrašnji prag od $20 \%$ uglavnom ne daje rezultate zbog kojih poluotvorene liste postoje, a to je preferencijalni uspjeh nižerangiranih kandidata na listama shodno volji glasača, koja može biti suprotna volji vrhova stranaka koji kreiraju redoslijed na listi. Visoki prag od 20\% ustvari „zatvara“ listu, pomaže da se ostvari bolja „ženska kvota“, ali istovremeno umanjuje važnost preferecijalnog glasanja i volje birača, pa ovom metodom u parlamente češće ulaze oni koje stranka želi, a ne oni koje narod želi.

\section{Pitanje vlasništva nad mandatom i poluzatvorene liste}

Jedno od stalnih pitanja reforme izbornog zakonodavstva jeste i pitanje vlasništva nad mandatom. Od donošenja Izbornog zakona BiH, logikom djelimično otvorenih listi, te neposrednog izbora predstavnika građana-birača, vlasništvo nad mandatom povjereno je samim kandidatima. Mandat, kao privremeno dato povjerenje ili transferirana volja birača, dato je time kao suvereno vlasništvo pojedinca, bez obzira na nivo vlastite zasluge ili kredibiliteta koji pojedinac ili stranka koju predstavlja ima. Posebna dilema se odnosi na vlasništvo nad kompenzacionim mandatom, iza kojeg, hipotetski, ne mora biti niti jedan osvojeni glas, već samo formalna kandidatura na bilo kojoj redovnoj listi. 
Ovakav model u teoriji ima za cilj da i kandidate i birače osposobi za puno razumijevanje neposredne demokratije, te podigne nivo političke odgovornosti nosilaca mandata spram građana-birača. Međutim, u sistemu dominirajuće partiokratije, odgovornost nosilaca parlamentarnih mandata nije proporcionalna važnosti neposrednog izbora i individualnog vlasništva nad mandatom, pa se nerijetko dešavaju transferi iz jedne u drugu stranku ili jednostavnije proglašavanje pojedinačnih zastupnika „nezavisnim“ od stranke koja ih je imala na listi i pod čijom značkom su osvojili mandat. Često je ova praksa u direktnoj vezi sa partikularnim interesom kada se formiraju određene parlamentarne većine, biraju vlade ili donose krupne političke ili zakonodavne odluke. Manipulacija i privatizacija mandatom stoga postaje kritična tačka izbornog i stranačkog sistema, s obzirom da nosilac mandata time deformira stranačku scenu i kakvu-takvu predvidivost parlamentarnog života.

Posebni izazov predstavljaju kompenzacione liste, kao i vlasništvo nad kompenzacionim mandatom. S obzirom da su kompenzacioni mandati rezultat ukupnog broja glasova nekog političkog subjekta, nije primjenjiv princip neposrednog legitimiteta kao kod redovnih mandata, pa bi stranačko vlasništvo nad kompenzacionim mandatom bila jedna od mogućnosti sprječavanja privatizacije i prebjega mandata iz jednog u drugi politički subjekt. Drugi izazov je način sastavljanja kompenzacione liste, koja bi se mogla formirati shodno pojedinačnom izbornom rezultatu kandidata koji ne osvoje redovne mandate. Time bi kompenzacione liste bile definirane nakon raspodjele redovnih mandata, a ne unaprijed, $\mathrm{tj}$. paralelno s redovnim listama, što bi ojačalo legitimitet nosiocima kompenzacionih mandata i dalo veliki doprinos neposrednoj demokratiji.

\section{Zastupljenost žena i manjinskih grupa}

Na Općim izborima 2018. godine, za učešće na izborima ovjereno je 41,6 posto kandidata ženskog spola, dok je mandate osvojilo tek 27,4 posto njih. Imperativna norma Izbornog zakona o minimalnoj kvoti od 40 posto zastupljenosti žena na listama jeste podigla nivo njihovog učešća listama, ali zbog modela u kojem su u pravilu muškarci nosioci listi, te preferencijalnog modela glasanja, procenat izabranih žena za 14 posto je niži od njihove zastupljenosti na listama. Javna je tajna da su izborne malverzacije najizraženije unutar listi političkih stranaka i to u pravilu na štetu ženskih kandidata. 
Također, zastupljenost drugih manjinskih ili marginaliziranih grupa poput nacionalnih manjina, osoba s invaliditetom, i sl., trebala bi biti garantirana određenim minimalnim kvotama.

Jednako bitno pitanje jeste nivo zastupljenosti žena u izvršnoj vlasti, primarno u vladama, ali i na pozicijama (grado)načelnika, direktora vladinih agencija, javnih preduzeća, vanbudžetskih fondova i drugih institucija, gdje je njihovo učešće upadljivo niže od parlamentarnog.

Propisivanjem drugačijih pravila koje će osigurati minimalno $40 \%$ učešća manje zastupljenog spola u zakonodavnoj vlasti, te približno toliko u izvršnoj, osiguraće jednakopravnost, te angažirati neiskorišteni socijalni kapital.

\section{Pitanje stope izlaznosti - mjera obaveznog glasanja na izborima}

Stopa izlaznosti u proteklih 10 izbornih ciklusa (2000-2018) kreće se od 47\% do 57\%. Ukoliko uzmemo u obzir činjenicu da je udio nevažećih glasačkih listića, ovisno o vrsti listića, odnosno nivou izbora, od 3\% do čak 10\%, dolazimo do zaključka da prosječno tek oko $50-52 \%$ glasača u potpunosti koristi svoje glasačko pravo, a njihovi glasovi budu transformirani u mandate. Uz par izuzetaka, parlamentarne većine i izbor izvršne vlasti u $\mathrm{BiH}$, počiva na prostim natpolovičnim većinama, pa dolazimo do zaključka da izvršna vlast, kroz cijeli mandatni period počiva na volji parlamentarnih većina čiji je izborni legitimitet približno između $25 \%$ i $35 \%$ od ukupnog broja glasova. Time vlade redovno borave u zoni stalne „,manjinske podrške“ građana, što, uz pomoć medija, proizvodi tenzije i "buku tihe većine".

Jedna od opcija o kojoj se može razgovarati, a koja bi drastično promijenila izborni kontekst jeste propisivanje obaveznog glasanja na izborima, kao što je to slučaj u nekoliko država EU (Belgija, Grčka, Luksemburg), kao i nizu neevropskih država (Argentina, Australija, Bolivija, Brazil, Kongo, Kostarika, Ekvador, Egipat, Honduras, Meksiko, Paragvaj, Peru, Singapur, Tajland, Urugvaj, itd.).

Dosta uporediv primjer za BiH jeste Belgija. Izlaznost na posljednjim parlamentarnim izborima u Belgiji iznosila je 89\%. Belgija je ujedno i zemlja koja ima najdužu tradiciju obaveznog glasanja još od 1892. godine. Svi građani koji navrše 18 godina u obavezi su da izađu na glasanje, a ako to ne učine suočavaju se sa umjerenim kaznama. Međutim, ukoliko birač ne izađe na izbore $u$ četiri izborna kruga on se suočava sa gubitkom prava glasa u trajanju od deset godina. 
U kontekstu Bosne i Hercegovine, razumijevajući da visoke stope izlaznosti mogu značajno korigirati malverzacije u procesu glasanja i brojanja, odnosno da statistika velikih brojeva može nadvladati krađu glasova, kupovinu glasova, glasanje mrtvih, „bugarske vozove“ i druge oblike izbornog inženjeringa, te podići nivo političke kulture, mjera obaveznog glasanja na izborima mogla bi presudno trasirati novi nivo demokratizacije i drugačije ishode političkog sistema Bosne i Hercegovine.

\section{Elektronsko glasanje i/ili brojanje}

Iako je duži niz godina ideja elektronskog glasanja i/ili brojanja u opticaju, iako su rađene određene simulacije i pokrenute zakonodavne inicijative za modernizaciju izbornog procesa, nikakvi krupni iskoraci u odnosu na prvobitni model glasanja nisu se desili. Nedovoljna kontrola toka glasanja, a posebno manuelno brojanje glasova, te dugi rokovi za objavu potvrđenih rezultata izbora, ostavljaju prostor za izborne i postizbrone malverzacije, pa bi tehnološka unapređenja eliminirala ili značajno umanjila ovu anomaliju.

Od velike je važnosti konačno uzeti u obzir brzi tehnološki napredak, te putem novih tehnoloških rješenja umanjiti korpuciju i sumnje u regularnost glasanja, a posebno brojanja na biračkim mjestima. Stoga su neki od ponuđenih modela (listići s bar-kodom, skeneri na glasačkim mjestima, cjelokupni softversko-hardverski paketi (mašine za elektronsko glasanje i trenutno brojanje), nadzorne kamere, i dr.), opcije koje se moraju uzeti u razmatranje pri optimizaciji izbornih pravila.

\section{Zaključak}

Navedenih jedanaest tačaka, iako ne obuhvataju sve izazove, predstavljaju kritični okvir za reformu izbornog zakonodavstva oko kojeg je moguće, ali i nužno postići politički i stručni kompromis, s ciljem zaštite narušenog integriteta izbornog sistema, te osiguravanja fer i poštenih izbora, kroz zaštitu izbornih principa: općeg, jednakog i tajnog prava glasa, te slobodnim i neposrednim izborima za sve državljane BiH s biračkim pravom. Demokratizacija i konsolidicija parlamentarne demokratije iziskuju temeljitu izbornu reformu - a to je rubikon koji se mora preći - conditio sine qua non! 


\section{Literatura}

Arendt, H., Totalitarizam, Politička kultura, Zagreb, 1996.

Arnautović, S., Političko predstavljanje i izborni sistemi u Bosni i Hercegovini u XX stoljeću, Promocult, Sarajevo, 2009.

Baradat, L., Political Ideologies: Their Origins and Impact, Prentice-Hall Publishers, Englewood Cliffs, 1994.

Beyme, K. v., Transformacija političkih stranaka, FPN, Zagreb, 2002.

Bieber, F. „Institucionaliziranje etniĉnosti: postignuća i neuspjesi nakon ratova u Bosni i Hercegovini, na Kosovu i u Makedoniji”, Forum Bosnae, 2004.

Fink Hafner, D., Pejanović, M. Razvoj političkog pluralizma u Sloveniji i Bosni i Hercegovini, Promocult, Sarajevo/Ljubljana, 2006.

Gavrić, S., Banović, D. (ur), Parlamentarizam u Bosni i Hercegovini, SOC, Saajevo, 2012.

Goati, V. et.al., Preporuke za izmenu izbornog zakonodavstva u Srbiji, Beograd, 2008.

Giddens, A., Beyond Left and Right, Polity Press, Oxford, 1994.

Heywood, A., Political Ideologies, Macmillan, London, 1992.

Heywood, A., Politics, Macmillan, London, 2002.

Kapidžić, D. Stranački sustav Bosne i Hercegovine. U: Arnautović, S.,(et.al.), Politički pluralizam i unutarstranačka demokracija: Bosna i Hercegovina (str.33-51). Podgorica: Centar za monitoring i istraživanje, 2015.

Kasapović, M. Izborni leksikon, Zagreb, 2003.

Macpherson, C. B., Individualism, U: The New Palgrave: A Dictionary of Economics, ur. J. Eatwell, M. Milgate and P. Newman, sir. 2, Macmillan, London, 1987.

Milardović, A. Političke stranke u doba tranzicije i globlizacije, Centar za politološka istraživanja, Zagreb, 2006.

Milardović, A. Uvod u politologiju, Panliber, Zagreb, 1997.

Mujkić, A. Pravda i etnonacionalizam, Sarajevo, 2010.

Nohlen, D. (ur), Politološki rječnik, Panliber, Zagreb, 1996/2001.

Pejanović, M. Politički razvitak Bosne i Hercegovine u postdjetnoskom periodu, Šahinpašić, Sarajevo, 2005.

Seiler, D. Političke stranke, Panliber, Zagreb, 1999. 


\title{
Critical Points for Improving the Electoral System of Bosnia and Herzegovina - Rubicon of Democratization
}

\begin{abstract}
Summary
The slow or blocked implementation of the election results after the 2018 General Elections deepened the overall political crisis in $\mathrm{BiH}$, so even 20 months after the elections, the election results were not fully implemented. The $\mathrm{BH}$ electoral system thus becomes a permanent catalyst for political blockades, and as such slows down or blocks the process of consolidating parliamentary democracy. The last three election cycles have undoubtedly confirmed the paradox of the electoral system and the Election Law. Namely, all relevant actors, from the election administration, through domestic and international independent election observers, to political entities themselves, although with a number of well-founded objections and documented anomalies in the election process, generally recognize election results and unanimously advocate thorough improvement of the electoral system. This study provides theoretical and empirical insight into key provisions of electoral legislation or critical points of the electoral system that must be innovated, redefined and modernized in order for the consolidation of parliamentary democracy, efficient political system, responsible executive and legislative power, and citizens' trust in the electoral system to become axioms. socio-political reforms in the process of EU and internal integration.
\end{abstract}

Key words: electoral system, electoral law, electoral principles, political parties 